The Numerical Age of the Upper Frasnian (Upper Devonian) Kellwasser Horizons: A New U$\mathrm{Pb}$ Zircon Date from Steinbruch Schmidt (Kellerwald, Germany)

Author(s): Bernd Kaufmann, Endres Trapp and Klaus Mezger

Source: The Journal of Geology, Vol. 112, No. 4 (July 2004), pp. 495-501

Published by: The University of Chicago Press

Stable URL: http://www.jstor.org/stable/10.1086/421077

Accessed: 20-09-2016 05:49 UTC

JSTOR is a not-for-profit service that helps scholars, researchers, and students discover, use, and build upon a wide range of content in a trusted digital archive. We use information technology and tools to increase productivity and facilitate new forms of scholarship. For more information about JSTOR, please contact support@jstor.org.

Your use of the JSTOR archive indicates your acceptance of the Terms \& Conditions of Use, available at http://about.jstor.org/terms

The University of Chicago Press is collaborating with JSTOR to digitize, preserve and extend access to The Journal of Geology 


\title{
The Numerical Age of the Upper Frasnian (Upper Devonian) Kellwasser Horizons: A New U-Pb Zircon Date from Steinbruch Schmidt (Kellerwald, Germany)
}

\author{
Bernd Kaufmann, Endres Trapp, ${ }^{1}$ and Klaus Mezger ${ }^{1}$ \\ Institut für Geowissenschaften, Universität Tübingen, Sigwartstrasse 10, 72076 Tübingen, Germany \\ (e-mail: bernd.kaufmann@uni-tuebingen.de)
}

\begin{abstract}
A B S T R A C T
Steinbruch Schmidt (Kellerwald, Germany) is probably the world's most famous locality that exposes the late Frasnian anoxic events (Kellwasser Crisis). A 3-cm-thick bentonite layer (Bed 36) is intercalated between the two Kellwasser horizons and can be precisely assigned to the Upper rhenana conodont Zone. Twenty-four U-Pb ID-TIMS (isotope dilution-thermal ionization mass spectrometryl analyses of single zircons extracted from this layer yielded 17 concordant results, which form an elongated cluster along concordia. The oldest point of this cluster is assumed to represent the lowest amount of $\mathrm{Pb}$ loss, and its ${ }^{206} \mathrm{~Pb} /{ }^{238} \mathrm{U}$ age of $377.2 \pm 1.7 \mathrm{Ma}$ is regarded as the eruption age of the bentonite. This dating allows the geochronological fixing of the anoxic Kellwasser horizons, which characterize one of the most important biotic crises of the Palaeozoic era, immediately prior to the Frasnian-Famennian boundary. A biochronometric timescale of the mid-Frasnian to late Famennian interval is established based on all recently published Late Devonian U-Pb ID-TIMS ages. The age of the Frasnian-Famennian boundary can be estimated by interpolation to $376.1 \pm 1.6 \mathrm{Ma}$.
\end{abstract}

\section{Introduction}

Most of our knowledge concerning the duration of changes in the geological record depends on time interpolation between relatively few isotopic ages, which are determined with different isotope systems and various analytical methods. Only a few of these ages are precise and biostratigraphically well controlled. On the basis of such ages, vastly differing in quality, comparatively imprecise and flawed timescales have been constructed in the past. Consequently, a methodically consistent data set of biostratigraphically well-constrained isotopic ages is the most important precondition for the construction of accurate timescales. High initial parent/daughter element ratios and a unique dual decay scheme make $\mathrm{U}-\mathrm{Pb}$ zircon ages more precise and reliable than most other isotopic ages and thus inherently superior for timescale calibration.

The late Frasnian anoxic events (Kellwasser ho-

Manuscript received June 24, 2003; accepted December 8, 2003.

${ }^{1}$ Zentrallabor für Geochronologie, Institut für Mineralogie, Universität Münster, Corrensstrasse 24, 48149 Münster, Germany. rizons) are closely linked to the Frasnian-Famennian mass extinction, which represents one of the five major bioevents of the Phanerozoic (Sepkoski 1982). The causes of this faunal crisis have been a matter of a long and vigorous debate (see reviews and references in Schindler 1990; Buggisch 1991; McGhee 1996; Racki and House 2002). However, no isotopic ages have been acquired so far that fix the timing and duration of these events. Previous estimates for the age of the Frasnian-Famennian boundary range from 364.0 to $376.5 \mathrm{Ma}$ (Harland et al. 1990; Fordham 1992; Young 1995; Sandberg and Ziegler 1996; Tucker et al. 1998; Compston 2000). This uncertainty is due to the lack of reliable and biostratigraphically well-constrained isotopic ages in the Late Devonian. To date, the age of 376.5 Ma of Tucker et al. (1998) represents the best estimate for the age of the Frasnian-Famennian boundary because it was interpolated between two isotope dilution-thermal ionization mass spectrometry (U-Pb ID-TIMS) zircon ages of the midFrasnian (Belpre Ash, $381.1 \pm 1.3 \mathrm{Ma}$ ) and the late Famennian (Piskahegan Group, $363.6 \pm 1.6 \mathrm{Ma}$ ). 


\section{Locality}

Steinbruch Schmidt is located at the eastern margin of the Rhenish Massif near the village of Bad Wildungen, Germany. It is one of the best investigated outcrops of the Kellwasser lithologies (Devleeschouwer et al. 2002 and references therein). Bed 36 bentonite is $3 \mathrm{~cm}$ thick and situated $0.5 \mathrm{~m}$ above the top of the Lower Kellwasser horizon and $2.7 \mathrm{~m}$ below the Frasnian-Famennian boundary (Schindler 1990; fig. 1). Steinbruch Schmidt is also a reference section for conodont zonation, spanning the interval from the Lower rhenana to the Middle triangularis Zone (Ziegler and Sandberg 1990). Bed 36 bentonite can be fixed accurately in the middle part of the Upper rhenana Zone (fig. 1).

\section{Analytical Methods}

$\mathrm{U}-\mathrm{Pb}$ zircon ages were acquired at the Zentrallabor für Geochronologie, Institut für Mineralogie, Universität Münster, Germany. Zircons were separated from Bed 36 bentonite using refinements of the procedure outlined by Winter (1981). Grains were then handpicked and sorted according to color, quality, and morphology. Zircons selected for analysis were inclusion and crack free, normal to long prismatic $(2: 1$ to $6: 1)$, clear, and colorless. Following air abrasion (Krogh 1982), a few samples were additionally leached for $2 \mathrm{hr}$ in concentrated $\mathrm{HF}-\mathrm{HNO}_{3}$ $(4: 1)$ at $80^{\circ} \mathrm{C}$. After washing in $7 \mathrm{~N} \mathrm{HNO}_{3}$ at $80^{\circ} \mathrm{C}$ for $25 \mathrm{~min}$, individual grains were placed in multisample Teflon microcapsules and dissolved for $4 \mathrm{~d}$ in concentrated $\mathrm{HF}_{-} \mathrm{HNO}_{3}(4: 1)$ at $180^{\circ} \mathrm{C}$. Subsequently, dissolved zircons were spiked with a mixed ${ }^{233} \mathrm{U}-{ }^{205} \mathrm{~Pb}$ tracer solution, dried at $80^{\circ} \mathrm{C}$, redissolved in $6 \mathrm{~N} \mathrm{HCl}$, and equilibrated at $180^{\circ} \mathrm{C}$ for $1 \mathrm{~d}$. After drying at $80^{\circ} \mathrm{C}$, the samples were loaded on a single Re filament using a mixture of silica gel and $6 \mathrm{~N} \mathrm{HCl}-0.25 \mathrm{~N} \mathrm{H}_{3} \mathrm{PO}_{4}$. Isotope ratios of $\mathrm{Pb}$ and $U$ were measured with a Daly-type detector in ion-counting mode on a VG Sector 54 thermal ionization mass spectrometer (TIMS). Low radiogenic $\mathrm{Pb}$ concentrations required isotope analyses by peak jumping. $\mathrm{Pb}$ and $\mathrm{U}\left(\mathrm{as} \mathrm{UO}_{2}^{+}\right.$) were run sequentially on the same filament at temperatures of $1250^{\circ}-1350^{\circ} \mathrm{C}$ and $1300^{\circ}-1450^{\circ} \mathrm{C}$, respectively. Average measured precision ( $2 \sigma$ error) of $\mathrm{Pb}$ isotope ratios was $0.8 \%\left({ }^{206} \mathrm{~Pb} /{ }^{204} \mathrm{~Pb}\right), 0.18 \%\left({ }^{207} \mathrm{~Pb} /{ }^{206} \mathrm{~Pb}\right)$, and $0.06 \%\left({ }^{206} \mathrm{~Pb} /{ }^{205} \mathrm{~Pb}\right)$. Ratios were corrected individually for mass fractionation by $1.4 \pm 0.8 \%$ o/ $\mathrm{amu}\left({ }^{207} \mathrm{~Pb} /{ }^{206} \mathrm{~Pb},{ }^{206} \mathrm{~Pb} /{ }^{205} \mathrm{~Pb}\right)$, and $1.5 \pm 0.8 \%$ o/amu $\left({ }^{206} \mathrm{~Pb} /{ }^{204} \mathrm{~Pb}\right)$, based on multiple analyses of NBS 982 standard. ${ }^{233} \mathrm{U} /{ }^{238} \mathrm{U}$ ratio was measured more pre-

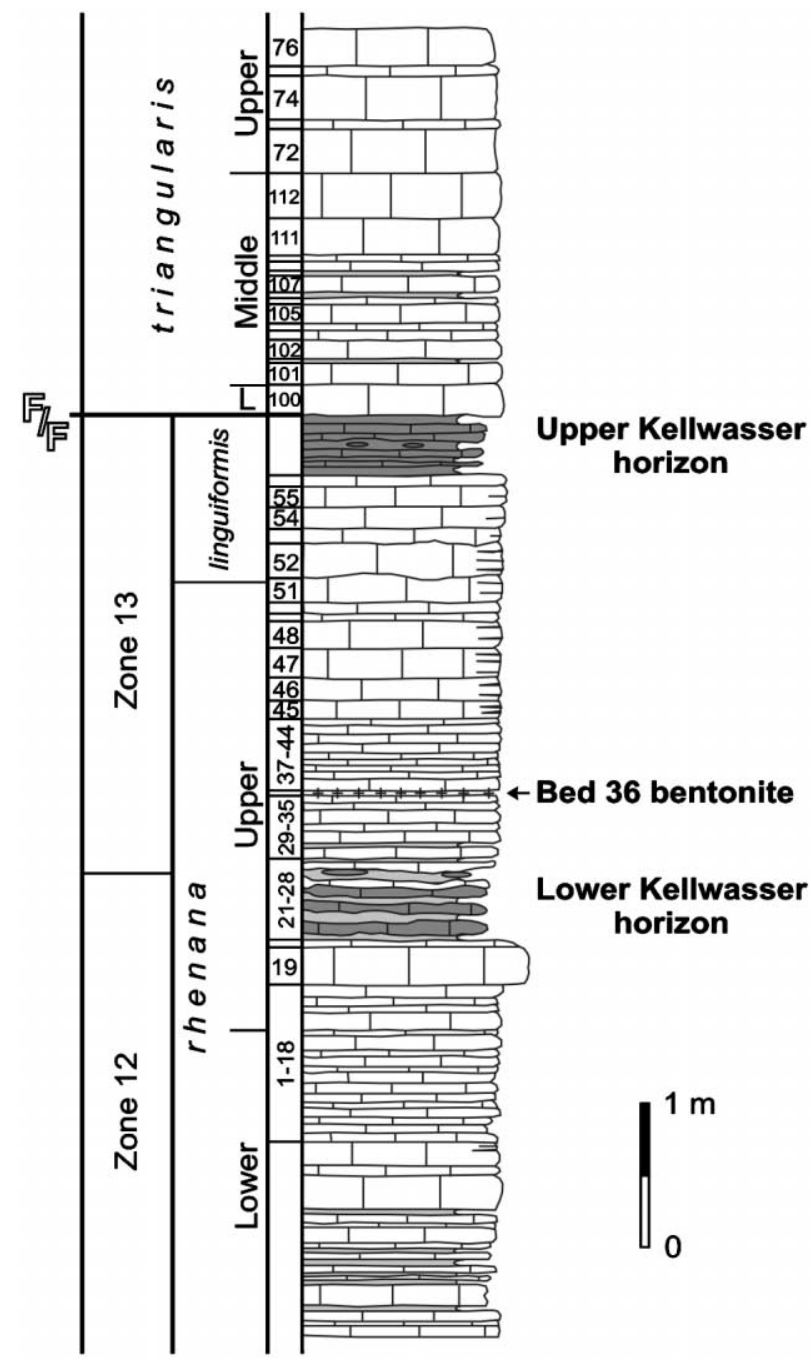

Figure 1. Lithologic column of Steinbruch Schmidt including conodont stratigraphy and position of Bed 36 bentonite (redrawn from Schindler 1990). Conodont stratigraphy based on Ziegler and Sandberg (1990).

cisely than $0.13 \%(2 \sigma)$, and mass fractionation was corrected by $2.0 \pm 0.8 \%$ /amu based on analyses of NBS 500 standard. For each charge of samples, the maximum $\mathrm{Pb}$ blank was assumed to be equivalent to the amount of the common $\mathrm{Pb}$ in the most radiogenic sample. Small sample volumes and low concentrations of $U$ were responsible for low radiogenic $\mathrm{Pb}$ amounts of 4.8 to $41.6 \mathrm{pg}$. Therefore, the highest possible reduction of the $\mathrm{Pb}$ blank was necessary. Due to extremely careful sample handling, the blank could be decreased in the course of the study from 3 to $1 \mathrm{pg}$. In all samples ${ }^{206} \mathrm{~Pb}_{\mathrm{rad}} /$ ${ }^{206} \mathrm{~Pb}_{\text {tot }}$ is sufficiently high to obtain precise ${ }^{206} \mathrm{~Pb} /$ 
${ }^{238} \mathrm{U}$ ages. The $\mathrm{U}$ blank was too small to be measured and was thus assumed to amount to $20 \%$ of the individual $\mathrm{Pb}$ blank based on experience with the analysis of milligram-sized samples. Uncertainties in ${ }^{206} \mathrm{~Pb} /{ }^{238} \mathrm{U},{ }^{207} \mathrm{~Pb} /{ }^{235} \mathrm{U}$, and ${ }^{207} \mathrm{~Pb} /{ }^{206} \mathrm{~Pb}$ ages were calculated using the algorithm of Ludwig (1980), and errors are quoted at the $2 \sigma$ level. Software Isoplot/Ex, rev. 2.49 (Ludwig 2001) was used for the concordia plot.

\section{Results}

The zircon population of Bed 36 bentonite shows an astonishing homogeneity with euhedral, normal-to-long prismatic shapes (fig. $2 A, 2 B$ ) and concentric growth zoning (fig. $2 C, 2 D$ ) as expected for magmatic zircons. Inherited zircons have not been detected by cathodoluminescence investigations, but two (samples 1.3 and 2.8) of 24 analyzed grains must have contained older cores as documented by their significant older ages (table 1). Concerning the effects of $\mathrm{Pb}$ loss, a slight but statistically significant trend toward concordance was observed in samples that were subjected to stronger air abrasion and additional HF leaching.

${ }^{206} \mathrm{~Pb} /{ }^{238} \mathrm{U}$ ages were determined with a typical precision of $0.4 \%$. However, due to small sample weights and low concentrations of ${ }^{207} \mathrm{~Pb}$ (at this age more than 18 times lower than ${ }^{206} \mathrm{~Pb}$ ), errors of the ${ }^{207} \mathrm{~Pb} /{ }^{235} \mathrm{U}$ (mean $1.2 \%$ ) and ${ }^{207} \mathrm{~Pb} /{ }^{206} \mathrm{~Pb}$ (mean $5.8 \%$ ) ages are much higher (table 1). Seventeen of 24 analyses are concordant and form an elongated cluster on the concordia plot (fig. 3). ${ }^{206} \mathrm{~Pb} /{ }^{238} \mathrm{U}$ ages of these points range from 359.2 to $377.2 \mathrm{Ma}$ (table 1), scattering significantly outside their analytical error. This indicates that at least some of the zircons are affected either by inheritance or Pb loss. Inheritance can most likely be excluded (see above), and the two conspicuously older analyses are clearly resolved from the cluster. Therefore, and because
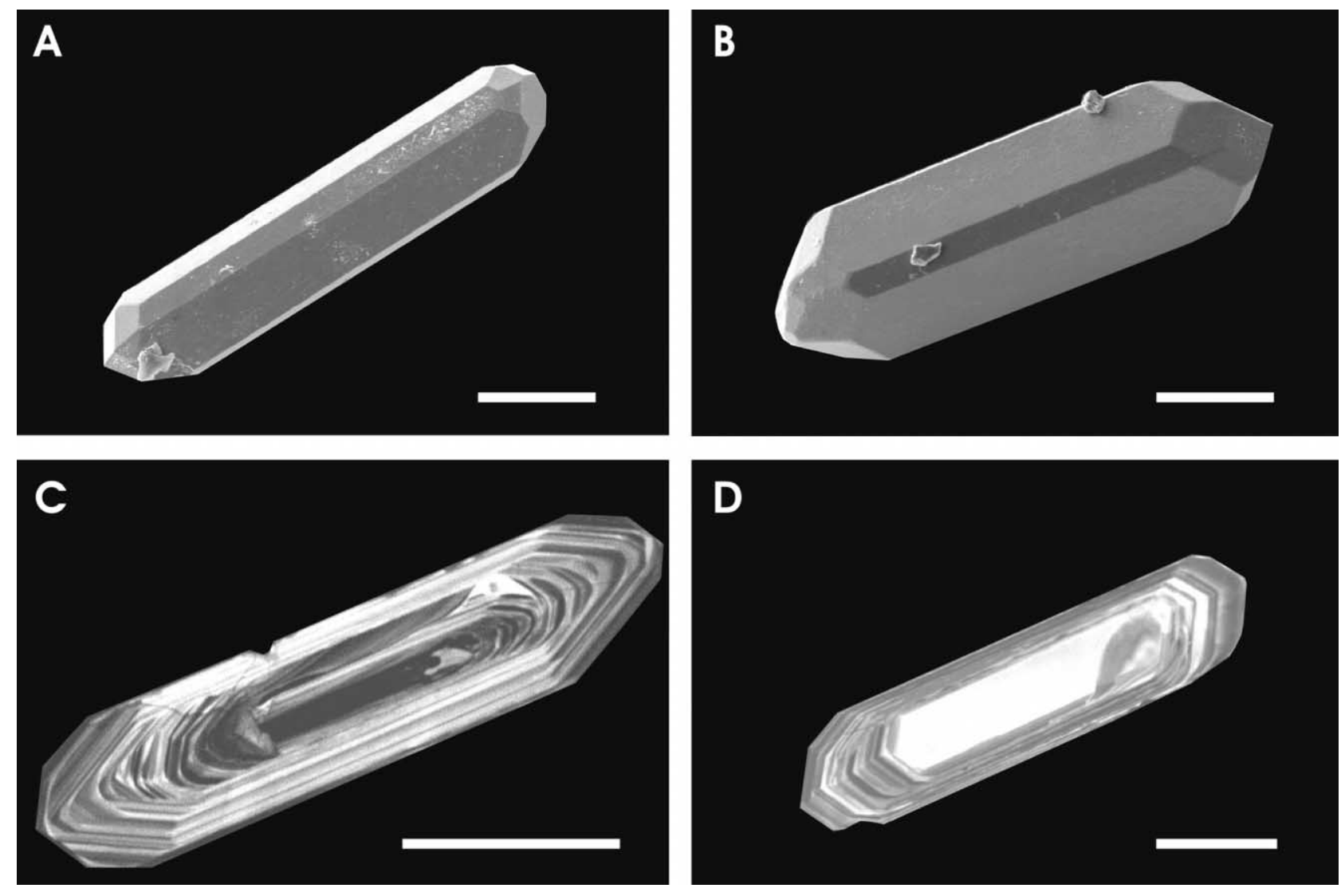

Figure 2. Scanning electron microscope and cathodoluminescence photographs of typical zircons from Bed 36 bentonite. Scale bar is $50 \mu \mathrm{m}$. $A$, Long prismatic zircon with $\{100\}>\{110\}$ and $\{101\}>\{211\}$. $B$, Normal prismatic zircon with $\{110\}>\{100\}$ and $\{101\}=\{211\}$. C, D, Zircons showing concentric growth zoning. 
Table 1. U-Pb Zircon Data of Steinbruch Schmidt Bed 36 Bentonite

\begin{tabular}{|c|c|c|c|c|c|c|c|c|c|c|c|}
\hline \multirow[b]{2}{*}{ Sample $^{\mathrm{a}}$} & \multirow[b]{2}{*}{$\begin{array}{c}\text { Weight } \\
(\mu \mathrm{g})^{\mathrm{b}}\end{array}$} & \multicolumn{3}{|c|}{ Concentration } & \multicolumn{4}{|c|}{ Isotopic ratio } & \multicolumn{3}{|c|}{ Isotopic age (Ma) } \\
\hline & & $\begin{array}{c}\mathrm{U} \\
(\mathrm{ppm})^{\mathrm{c}}\end{array}$ & $\begin{array}{l}\text { Pb rad. } \\
(\mathrm{pg})^{\mathrm{c}}\end{array}$ & $\begin{array}{l}\mathrm{Pb} \text { com. } \\
(\mathrm{pg})^{\mathrm{d}}\end{array}$ & $\begin{array}{l}{ }^{206} \mathrm{~Pb} / \\
{ }^{204} \mathrm{~Pb}^{\mathrm{e}}\end{array}$ & $\begin{array}{c}{ }^{206} \mathrm{~Pb} /{ }^{238} \mathrm{U} \\
( \pm \%)^{\mathrm{f}}\end{array}$ & $\begin{array}{c}{ }^{207} \mathrm{~Pb} /{ }^{235} \mathrm{U} \\
( \pm \%)^{\mathrm{f}}\end{array}$ & $\begin{array}{c}{ }^{207} \mathrm{~Pb} /{ }^{206} \mathrm{~Pb} \\
( \pm)^{\mathrm{f}}\end{array}$ & ${ }^{206} \mathrm{~Pb} /{ }^{238} \mathrm{U}^{\mathrm{f}}$ & ${ }^{207} \mathrm{~Pb} /{ }^{235} \mathrm{U}^{\mathrm{f}}$ & ${ }^{207} \mathrm{~Pb} /{ }^{206} \mathrm{~Pb}^{\mathrm{f}}$ \\
\hline 1.0. $180 \mu \mathrm{m}, 3.5: 1,-\mathrm{a}^{\mathrm{g}}$ & 1.7 & 222 & & .7 & 372 & $.05839(.4)$ & $3742(.8)$ & $.05433(34)$ & $365.8 \pm 1.4$ & $368.4 \pm 2.9$ & $385 \pm 14$ \\
\hline 1.0. $180 \mu \mathrm{m}, 4: 1,-\mathrm{a}$ & 1.3 & 132 & 6.8 & .3 & 207 & $.05906(.5)$ & $.44159(1.7)$ & $.05423(78)$ & $369.9 \pm 1.7$ & $371.4 \pm 6.2$ & $380 \pm 33$ \\
\hline 1.3. $150 \mu \mathrm{m}, 3: 1,-\mathrm{a}^{\mathrm{h}}$ & 1.4 & 255 & 18.2 & 6.1 & 181 & $.06713(.4)$ & $.53172(1.1)$ & $.05745(53)$ & $418.8 \pm 1.6$ & $432.9 \pm 4.7$ & $509 \pm 20$ \\
\hline 1.4. $160 \mu \mathrm{m}, 5: 1,-\mathrm{a}$ & .8 & 439 & 24.6 & 1.2 & 314 & $.05906(.4)$ & $.44226(1.1)$ & $.05431(52)$ & $369.9 \pm 1.4$ & $371.8 \pm 4.1$ & $384 \pm 21$ \\
\hline 1.5. $230 \mu \mathrm{m}, 6: 1,-\mathrm{a}$ & .9 & 308 & 17.1 & 2.0 & 213 & $.05775(.4)$ & $.43231(1.1)$ & $.05430(51)$ & $361.9 \pm 1.6$ & $364.8 \pm 4.1$ & $383 \pm 21$ \\
\hline 1.6. $150 \mu \mathrm{m}, 3: 1,-\mathrm{a}$ & 1.4 & 218 & 11.6 & $<.1$ & 361 & $.05868(.4)$ & $.43726(.9)$ & $.05405(40)$ & $367.6 \pm 1.4$ & $368.3 \pm 3.4$ & $373 \pm 17$ \\
\hline 1.7. $230 \mu \mathrm{m}, 3: 1,-\mathrm{a}^{\mathrm{g}}$ & 2.1 & 156 & 10.4 & 8.7 & 120 & $.05807(.5)$ & $.43926(1.8)$ & $.05486(87)$ & $363.9 \pm 1.6$ & $369.7 \pm 6.6$ & $406 \pm 36$ \\
\hline 2.3. $160 \mu \mathrm{m}, 2.5: 1,+\mathrm{a}$ & 1.7 & 155 & 8.5 & $<.1$ & 437 & $.05896(.4)$ & .43845 (.9) & $.05393(42)$ & $369.3 \pm 1.5$ & $369.2 \pm 3.5$ & $368 \pm 18$ \\
\hline 2.8. $210 \mu \mathrm{m}, 5: 1,+\mathrm{a}^{\mathrm{h}}$ & 2.0 & 113 & 7.4 & $<.1$ & 445 & $.07037(.4)$ & $.54361(.8)$ & $.05603(34)$ & $438.4 \pm 1.8$ & $440.8 \pm 3.5$ & $454 \pm 13$ \\
\hline 3.1. $150 \mu \mathrm{m}, 3: 1,+\mathrm{a}, \mathrm{hf}^{\mathrm{g}}$ & .7 & 704 & 40.3 & .9 & 674 & $.05840(.4)$ & $.43712(.6)$ & $.05428(21)$ & $365.9 \pm 1.5$ & $368.2 \pm 2.1$ & $383 \pm 8$ \\
\hline 3.3. $210 \mu \mathrm{m}, 4: 1,+\mathrm{a}, \mathrm{hf}$ & 1.8 & 89 & & .4 & 301 & $.05851(.4)$ & $.44102(1.4)$ & $.05467(66)$ & $366.5 \pm 1.5$ & $371.0 \pm 5.1$ & $399 \pm 28$ \\
\hline 3.4. $150 \mu \mathrm{m}, 3: 1,+\mathrm{a}, \mathrm{hf}$ & .8 & 211 & 11.5 & $<.1$ & 372 & $.05963(.4)$ & $.44608(1.0)$ & $.05425(44)$ & $373.4 \pm 1.5$ & $374.5 \pm 3.7$ & $382 \pm 18$ \\
\hline 3.5. $160 \mu \mathrm{m}, 2.5: 1,+\mathrm{a}, \mathrm{hf}^{\mathrm{g}}$ & 1.7 & 318 & 18.0 & 6.7 & 228 & $.05214(.4)$ & $.39411(1.8)$ & $.05482(93)$ & $327.6 \pm 1.3$ & $337.4 \pm 6.0$ & $405 \pm 37$ \\
\hline $0 \mu \mathrm{m}, 3: 1,+\mathrm{a}, \mathrm{hf}$ & 1.0 & 273 & & 6.7 & 140 & $.05812(.6)$ & $.43340(2.3)$ & $.05408(113)$ & $364.2 \pm 2.1$ & $.6 \pm 8.5$ & $375 \pm 48$ \\
\hline $0 \mu \mathrm{m}, 3: 1,+\mathrm{a}, \mathrm{hf}$ & .9 & 462 & 2 & 6.7 & 198 & $.05805(.4)$ & $.43591(1.3)$ & $.05446(63)$ & $363.8 \pm 1.4$ & $367.4 \pm 4.7$ & $390 \pm 26$ \\
\hline $0 \mu \mathrm{m}, 3: 1,+\mathrm{a}, \mathrm{hf}$ & .8 & 546 & & 6.7 & 218 & $.06006(.4)$ & $.44860(1.6)$ & $.05417(81)$ & $376.0 \pm 1.5$ & $376.3 \pm 6.0$ & $378 \pm 33$ \\
\hline $0 \mu \mathrm{m}, 3: 1,+\mathrm{a}, \mathrm{hf}$ & .9 & 301 & 16.5 & $<.1$ & 438 & $.05816(.4)$ & $.43189(.7)$ & $.05386(28)$ & $364.4 \pm 1.3$ & $364.5 \pm 2.5$ & $365 \pm 12$ \\
\hline 4.4. $180 \mu \mathrm{m}, 3.5: 1,+\mathrm{a}, \mathrm{hf}$ & 1.5 & 173 & 9.7 & $<.1$ & 580 & $.05931(.4)$ & $.44270(.7)$ & $.05413(30)$ & $371.4 \pm 1.4$ & $372.2 \pm 2.7$ & $377 \pm 12$ \\
\hline$\mu \mathrm{m}, 3: 1,+\mathrm{a}, \mathrm{hf}$ & 1.0 & 130 & 7 & .3 & 288 & $.06001(.4)$ & $.44803(1.3)$ & $.05415(58)$ & $375.7 \pm 1.6$ & $375.9 \pm 4.7$ & $377 \pm 24$ \\
\hline 5.0. $210 \mu \mathrm{m}, 5: 1,+\mathrm{a}, \mathrm{hf}$ & 2.1 & 148 & 8.9 & 1.4 & 518 & $.05960(.4)$ & $.44247(.8)$ & $.05385(35)$ & $373.2 \pm 1.4$ & $372.0 \pm 2.9$ & $365 \pm 14$ \\
\hline 5.1. $160 \mu \mathrm{m}, 2.5: 1,+\mathrm{a}, \mathrm{hf}$ & 1.5 & 1 & 7 & $<.1$ & 716 & $.05970(.4)$ & $.44614(.8)$ & $.05420(35)$ & $373.8 \pm 1.4$ & $374.6 \pm 3.0$ & $379 \pm 15$ \\
\hline$: 1,+a, h f$ & 1.8 & 109 & 6.3 & .3 & 639 & $.05966(.4)$ & $.44650(.7)$ & $.05427(32)$ & $373.6 \pm 1.4$ & $374.8 \pm 2.8$ & $382 \pm 13$ \\
\hline , $+\mathrm{a}, \mathrm{hf}$ & .8 & & 11.2 & .5 & 430 & .05949 (.4) & $.44426(1.0)$ & $.05416(48)$ & $372.5 \pm 1.4$ & $373.3 \pm 3.8$ & $378 \pm 20$ \\
\hline 5.5 .2 & 1.7 & 296 & 17.6 & 3.9 & 394 & $.05681(.4)$ & $.42635(.8)$ & $.05443(37)$ & $356.2 \pm 1.4$ & $360.6 \pm 3.0$ & $389 \pm 15$ \\
\hline
\end{tabular}

${ }^{a} 200 \mu \mathrm{m}=$ length of grain; $3: 1=$ length : width ratio; $-\mathrm{a}=\operatorname{slightly}$ abraded $(\sim 10 \%$ reduction of crystal volume $) ;+\mathrm{a}=$ strongly abraded $(\sim 30 \%$ reduction $) ;$ hf $=$ HF leached. ${ }^{\mathrm{b}}$ Estimated $( \pm 30 \%)$ from crystal length and shape.

Calculations based on estimated weight.

${ }^{\mathrm{d}}$ Corrected for $\mathrm{Pb}$ blank and spike contribution.

Measured value corrected for mass discrimination and fractionation.

${ }^{\mathrm{f}}$ Ratios and ages corrected for mass discrimination and fractionation, spike, Pb blank, and initial common Pb (at $376 \mathrm{Ma}$ from Stacey and Kramers 1975 ).

${ }^{\mathrm{g}}$ Denotes discordant zircon analysis caused by significant recent $\mathrm{Pb}$ loss; not displayed in the concordia plot.

${ }^{\mathrm{h}}$ Denotes zircon analyses with isotopic evidence for inheritance; not displayed in the concordia plot. 


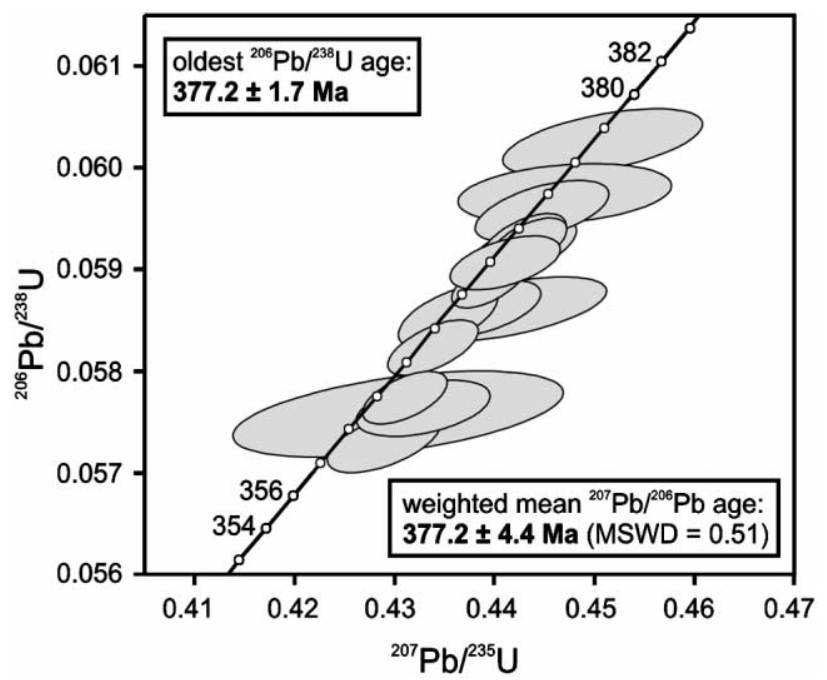

Figure 3. Concordia plot of 17 concordant single-zircon analyses of Bed 36 bentonite.

individual error ellipses are more or less homogeneously distributed within the cluster, the simplest explanation of the age scatter is Pb loss. If this interpretation is correct, the oldest point represents the lowest amount of $\mathrm{Pb}$ loss, and its ${ }^{206} \mathrm{~Pb} /{ }^{238} \mathrm{U}$ age of $377.2 \pm 1.7 \mathrm{Ma}$ can be regarded as the time of eruption of the bentonite. This age is confirmed by the identical weighted mean ${ }^{207} \mathrm{~Pb} /{ }^{206} \mathrm{~Pb}$ age $(377.2 \pm 4.4 \mathrm{Ma}, \mathrm{MSWD}=0.51)$ based on all concordant points.

\section{Timescale Implications}

The age of $377.2 \pm 1.7 \mathrm{Ma}$ of Bed 36 bentonite fits well into the timescale of Tucker et al. (1998), which is also based on U-Pb ID-TIMS zircon ages (fig. 4). It is bracketed by the mid-Frasnian Belpre Ash $(381.1 \pm 1.3 \mathrm{Ma})$ and the late Famennian Piskahegan Group $(363.6 \pm 1.6 \mathrm{Ma})$. The age of the latter has meanwhile been confirmed by a U-Pb monazite age obtained from the Nordegg Tuff of the late Famennian Exshaw Shale in southwestern Canada (Richards et al. 2002). If all these Late Devonian U-Pb ID-TIMS ages are treated equally, a recalibration and more precise rendering of the mid-Frasnian to late Famennian interval is possible. For this purpose, approximately time-linear biostratigraphic scales are used here for interpolation between the isotopic ages. The biostratigraphic scales were obtained from conodont-bearing sec- tions with homogeneous lithologies that reflect more or less uniform rock accumulation rates. These in turn are the precondition for an approximately linear record of time. A proportionate presentation of biozonal lengths as shown here is much more reliable than bioschemes based on the assumption that biozones represent equal time intervals. For interpolation, the biostratigraphic scales have now been spanned between each two successive isotopic ages: at first, between the ages of the Belpre Ash and Steinbruch Schmidt and subsequently between the Steinbruch Schmidt age and the coeval Piskahegan Group/Exshaw Formation ages (fig. 5). The result is a biochronometric timescale that allows the assignment of a numeric age with its error to each biozone boundary in the midFrasnian to late Famennian interval (fig. 5). The numerical age of the Frasnian-Famennian boundary is estimated by interpolation to $376.1 \pm 1.6 \mathrm{Ma}$. We regard a biochronometric timescale constructed in this manner as the closest approach to the "true" timescale that can be achieved based on the currently available data.

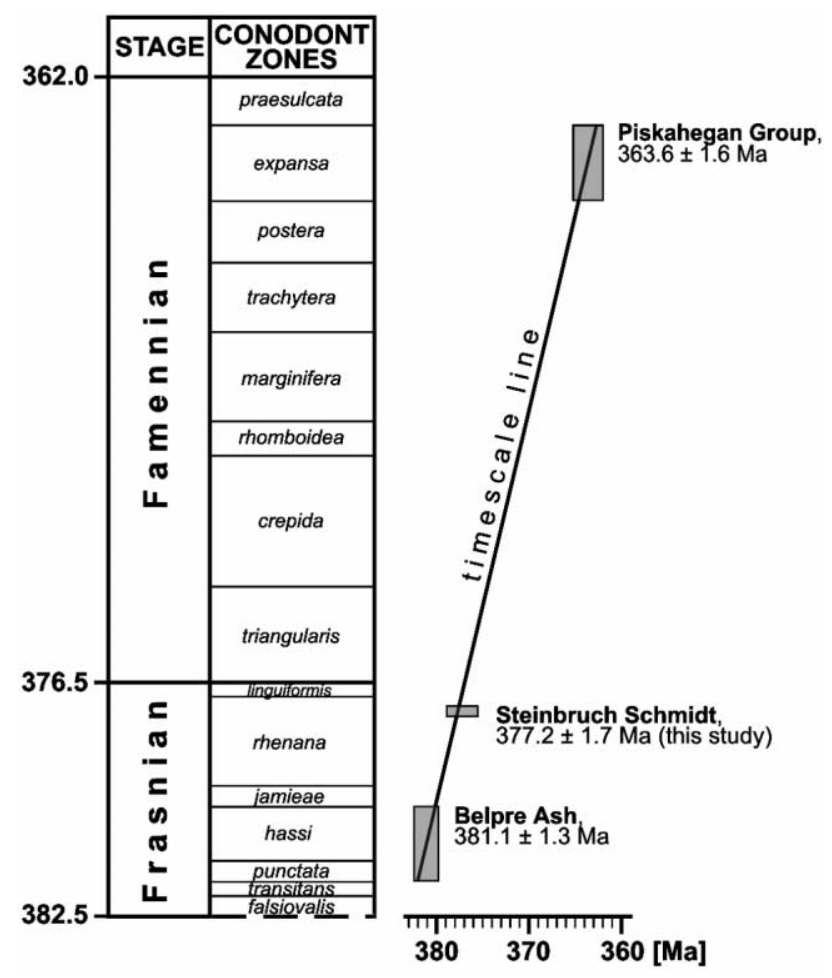

Figure 4. Plot of the U-Pb zircon age of Steinbruch Schmidt into the timescale (redrawn) of Tucker et al. (1998). 


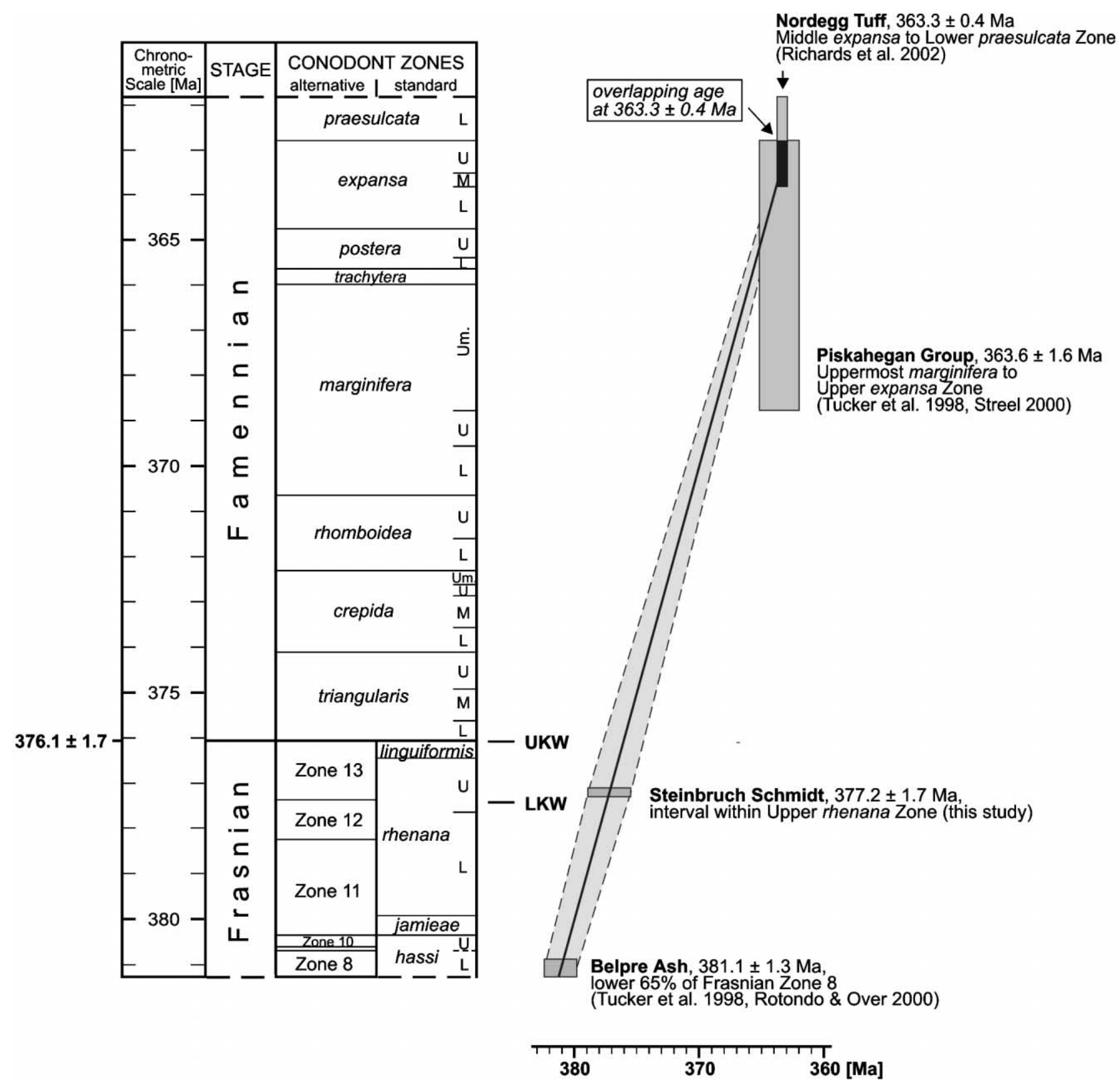

Figure 5. Late Frasnian to late Famennian biochronometric timescale. The biostratigraphic scale was obtained from the conodont sections at the Montagne Noire in France (hassi to crepida Zone; Klapper 1997) and at Lali in China (crepida to praesulcata Zone; Ji and Ziegler 1993). Correlation of standard with alternative conodont zones of the Frasnian is based on Klapper and Becker (1999). LKW = Lower Kellwasser horizon, UKW = Upper Kellwasser horizon.

\section{A C K N O W L E D G M E N T S}

Funding for this study was provided by the Deutsche Forschungsgemeinschaft (DFG, grant KA 1650/1-2). E. Schindler (Frankfurt) is acknowledged for the information on the bentonite occurrence at
Steinbruch Schmidt. Technical assistance was given by H. Bayer (Münster), G. Höckh, and Thomas Most (both Tübingen). Journal reviewers I. Bindeman (Caltech) and M. D. Schmitz (Washington) improved the manuscript with their constructive comments. 


\section{R E F E R E N C E S C I T E D}

Buggisch, W. 1991. The global Frasnian-Famennian "Kellwasser Event." Geol. Rundsch. 80:49-72.

Compston, W. 2000. Interpretations of SHRIMP and isotope dilution zircon ages for the Palaeozoic time-scale. II. Silurian to Devonian. Mineral. Mag. 64:1127-1146.

Devleeschouwer, X.; Herbosch, A.; and Préat, A. 2002. Microfacies, sequence stratigraphy and clay mineralogy of a condensed deep-water section around the Frasnian/Famennian boundary (Steinbruch Schmidt, Germany). Palaeogeogr. Palaeoclimatol. Palaeoecol. 181:171-193.

Fordham, B. G. 1992. Chronometric calibration of midOrdovician to Tournaisian conodont zones: a compilation from recent graphic-correlation and isotope studies. Geol. Mag. 129:709-721.

Harland, W. B.; Armstrong, R. L.; Cox, A. V.; Craig, L. E.; Smith, A. G.; and Smith, D. G. 1990. A geologic time scale 1989. Camb. Earth Sci. Ser., 263 p.

Ji, Q., and Ziegler, W. 1993. Lali section: an excellent reference section for Upper Devonian in south China. Cour. Forschungsinst. Senckenb. 157:1-183.

Klapper, G. 1997. Graphic correlation of Frasnian (Upper Devonian) sequences in Montagne Noire, France, and western Canada. Geol. Soc. Am. Spec. Pap. 321:113129.

Klapper, G., and Becker, R. T. 1999. Comparison of Frasnian (Upper Devonian) conodont zonations. Boll. Soc. Paleontol. Ital. 37:339-348.

Krogh, T. E. 1982. Improved accuracy of U-Pb zircon ages by the creation of more concordant systems using an air abrasion technique. Geochim. Cosmochim. Acta 46:637-649.

Ludwig, K. R. 1980. Calculation of uncertainties of U-Pb isotope data. Earth Planet. Sci. Lett. 46:212-220.

—. 2001. Isoplot/Ex, rev. 2.49: a geochronological toolkit for Microsoft Excel. Berkeley Geochronology Center, Spec. Publ. 1a, 55 p.

McGhee, G. R., Jr. 1996. The Late Devonian mass extinction: the Frasnian/Famennian crisis. New York, Columbia University Press, 303 p.

Racki, G., and House, M. R., eds. 2002. Late Devonian biotic crisis: ecological, depositional and geochemical records. Paläogeogr. Paläoclimatol. Paläoecol. 181:1374.

Richards, B. C.; Ross, G. M.; and Utting, J. 2002. U-Pb geochronology, lithology and biostratigraphy of tuff in the upper Famennian to Tournaisian Exshaw Formation: evidence for a mid-Paleozoic magmatic arc on the northwestern margin of North America. Can. Soc. Petrol. Geol. Mem. 19:158-207.

Rotondo, K. A., and Over, J. D. 2000. Biostratigraphic age of the Belpre Ash (Frasnian), Chattanooga and Rhinestreet shales in the Appalachian Basin. Geol. Soc. Am. Abstr. Program 32:A-70.

Sandberg, C. A., and Ziegler, W. 1996. Devonian conodont biochronology in geologic time calibration. Senckenb. Lethaea. 76:259-265.

Schindler, E. 1990. Die Kellwasser-Krise (hohe FrasneStufe, Ober-Devon). Gött. Arb. Geol. Palaeontol. 46: $1-115$.

Sepkoski, J. J., Jr. 1982. Mass extinctions in the Phanerozoic oceans: a review. Geol. Soc. Am. Spec. Pap. 190: 283-289.

Stacey, J. S., and Kramers, J. D. 1975. Approximation of terrestrial lead isotope evolution by a two-stage model. Earth Planet. Sci. Lett. 26:207-221.

Streel, M. 2000. The late Famennian and early Frasnian datings given by Tucker et al. (1998) are biostratigraphically poorly constrained. Subcommission on Devonian Stratigr. Newsl. 17:59.

Tucker, R. D.; Bradley, D. C.; Ver Straeten, C. A.; Harris, A. G.; Ebert, J. R.; and McCutcheon, S. R. 1998. New $\mathrm{U}-\mathrm{Pb}$ zircon ages and the duration and division of $\mathrm{De}-$ vonian time. Earth Planet. Sci. Lett. 158:175-186.

Winter, J. 1981. Exakte tephrostratigraphische Korrelation mit morphologisch differenzierten Zirkonpopulationen (Grenzbereich Unter-/Mitteldevon, EifelArdennen). Neues Jahrb. Geol. Palaeontol. Abh. 162: 97-136.

Young, G. C. 1995. Australian Phanerozoic timescales. 4. Devonian. Australian Geological Survey Organisation, Record 1995/33, 47 p.

Ziegler, W., and Sandberg, C. A. 1990. The Late Devonian standard conodont zonation. Cour. Forschungsinst. Senckenb. 121:1-115. 